\title{
Effect of Fibroblast Growth Factor (FGF) on Some Serum Oxidative Parameters in Hyperglycemic Rats
}

\section{Esra Oguz $^{1}$ (D) Sule Coskun Cevher ${ }^{2}$ (i)}

${ }^{1}$ Gazi University, Department of Biophysics,!Ankara, Turkey

${ }^{2}$ Gazi University, Department of Biology, Ankara,!Turkey

A B S T R AC T
pathways and has some successive healing periods. Most growth factor is responsible
for wound healing. Fibroblast growth factor has a positive effect on wound healing prob-
lems that can be caused by diabetes. In the present study, we aimed to investigate the effect
of bFGF applied to dorsolateral incision wounds in hyperglycemic rats on time-dependent
serum oxidative events by measuring serum TBARS, NOx and RSH. Experiments were
performed on 30 male Wistar albino rats (weight range:170-250 g ). Rats were hyperglyce-
mic with streptozotocin (ip, $60 \mathrm{mg} / \mathrm{kg}$ ). Experimental groups were divided into subgroups
with and without treatment according to the days. bGF was applied locally to the dor-
salateral wounds of rats ( $10 \mathrm{ng} / \mathrm{ml}$ ). After these administrations, on the 3th and 7 th days
of wound healing, the animals were sacrificed. Serum TBARS, RSH and NOx levels were
recorded spectrophotometrically. The results were expressed as mean \pm Standard deviation
and the mean differences were compared by Anova Variance Analysis (p<0,05). When
compared with the treatment group, on the 7 th day and the $3 \mathrm{rd}$ day, it was found that the
serum TBARS levels increased statistically in hyperglycemic rats(p<0,05). Both in the 3 rd
day of the untreated and 3rd day of the rats treated with bFGF may significant decrease in
the serum RSH levels. bFGF application was found both enhancing and reducing effects
on oxidative stres. In subsequent studies, the effect of bFGF, which has positive effects on
diabetic wound healing, on oxidative events can be investigated in detail using different
doses and different treatment periods.

\author{
Article History: \\ Received: 2021/07/12 \\ Accepted: 2021/og/26 \\ Online: 2021/12/31
}

Correspondence to: Esra Oguz,

Gazi University, Department of Biophysics, 06500, Ankara, Turkey.

E-Mail:esraoguz8916@gmail.com

Phone: +90 (542) 2845833

\section{Keywords:}

bFGF; Diabetic wound healing; Free radicals; Oxidative stress; Diabetes mellitus

\section{INTRODUCTION}

$\mathrm{R}$ epair of tissue damage, loss or deterioration in tissue continuity is one of the most important functions of the organism. The purpose of this repair is to ensure tissue integrity and the function of the damaged organ [1]. The healing of damaged tissue is provided by a regular, in-line of cellular and biochemical chain of events $[2,3]$.

Wound healing is an evolutionarily preserved complex process aimed at tissue restoration. The wound healing process includes separate but intertwined stages of inflammation, cellular proliferation and maturation and remodeling $[4,5]$. Each step; It takes place through the integration of a series of events controlled by endogenous and exogenous factors. This process is regulated by growth factors, cytokines and chemokines [6].

Growth factors are molecules with polypeptide structure that stimulate the growth, differentiation and proliferation of cells $[7,8]$. Studies conducted in recent years have shown that Fibroblast Growth Factor is a large family consisting of 28 members. FGFs produced by keratinocytes, fibroblasts, endothelium, smooth muscle ant mast cells have characteristically high binding affinity for both heparin ant fibroblast growth factor receptors. Endothelial cells have the ability to both express ant respond to FGF [9-11] . bFGF is often used clinically; it has been emphasized that it has a significant effect on wound healing in the skin, cornea, eardrum ant salivary glands[12, 13].

Diabetes mellitus (DM) is a metabolic disease that occurs as a result of disorders in insulin secretion as a result of the interaction of genetic, environmental factors, lifestyle changes and events caused by the immune system. It is characterized by hyperglycemia[14, 15]. Inflammation, angiogenesis and collagen synthesis are impaired in diabetes. Blood circulation in the wound area 
is negatively affected by the angiopathy and neuropathic effects of diabetes. Diabetes is a disease involving peripheral tissue injuries caused by oxidative stress caused by chronic hyperglycemia. Diabetes is known to cause an increase in oxidative stress and inflammatory response. Delayed wound healing is associated with an inflammatory response induced by hyperglycemia. This suggests that the effect of oxidative stress ant inflammatory response on wound healing may be positively affected by antioxidant supplementation. Diabetic scar; characterized by a disturbance in the wound healing process, according to animal experiments, a significant decrease in tensile strength was observed, particularly in inflammatory and proliferative phases, pathological angiogenesis and wound healing. Diabetes increases apoptosis of lymphocytes and increases the production of reactive oxygen species, also stimulating the signaling pathway of apoptosis [15-17].

Free radicals affect cellular structures and affect important components such as lipids, proteins, carbohydrates, DNA and enzymes[18]. There are many studies emphasizing the importance of reactive oxygen species in diabetic vascular pathogenesis and showing that diabetic complications are associated with oxidative stress[19].

Oxidative stress, which is one of the causes of diabetes, causes biological problems in wound healing. Considering that the mechanism of action of free radicals on wound healing is not clear, reducing the resulting products will affect the healing process. Many growth factors are effective against free radicals in wound healing.There are studies in which bFGF plays an important role in accelerating healing and biochemically.It is known that bFGF activity is high in the first 3 days of the healing process. However, studies showing the time-dependent effects of bFGF are insufficient. We aimed to measure the positive effect of bFGF, which is used in wound healing and whose doses are tried to be determined, against oxidative stress in the healing process in diabetic rats with biochemical parameters. Therefore, serum TBARS, RSH and NOx levels were measured spectrophotometrically in this study.

\section{MATERIAL AND METHODS}

The studies were initiated with the permission of Gazi University Experimental Animals Ethics Committee (G.Ü. ET-15.032) and all stages until the tissue samples were taken in Gazi University Laboratory Animal Breeding and Experimental Research Center (GÜDAM) laboratory. In the experiments, $30 \mathrm{Wistar}$ albino male rats, 170-250 grams, obtained from GÜDAM were used. Before animals fed with free feed and water and during the experiment were looked after in individual cages during the experiment, in an environment illuminated in pa- rallel with the daylight cycle. Tissue samples taken were analyzed in Gazi University Faculty of Science, Physiology-Biochemistry research laboratory.

\section{bFGF Preparation}

In previous studies conduced in our laboratory, the dosage was determined as 10ng / $\mathrm{ml}$, since it was determined histologically that the contribution of bFGF to wound healing at a dosage of 10ng / $\mathrm{ml}$ was high. bFGF (10 ng / $\mathrm{ml}$ ) was applied locally to the wounds of rats in the bFGF applied groups once a day at approximately the same time[20-22].

\section{Diabetes Model}

In groups formed to compare wound healing in healthy and diabetic animals, streptozotocin (STZ)(ip, $60 \mathrm{mg} /$ $\mathrm{kg})$ dissolved in $0.1 \mathrm{M}$ citrate buffer $(\mathrm{pH} 4.5)$ buffer was administered to diabetic animals[23]. One week later, blood glucose levels were measured with a glucometer and those above $300 \mathrm{mg} / \mathrm{dl}$ were considered as having diabetes. In contrast to the experimental animals that were resistant to diabetes, STZ administration was made in a second dose and made diabetic.

\section{Wound Model}

In order to prevent infection before the experiment, the dorsal parts of the animals were made ready by applying batticon before the wound was created.

General anesthesia was provided by weighing the experimental animals on a standard scale and injecting ketamine (Alfamanine 50mg / kg) and xylazine (Alfazyne $5 \mathrm{mg} / \mathrm{kg}$ ) intramuscularly according to their weight.

Dorsolateral excisional incision wounds were made on the dorsal of the animals, approximately $4 \mathrm{~cm}$ long on both sides of the spine [24-26]. Later, the wound lips were adapted with suture. In order to provide postoperative analgesia, paracetamol, a pharmacological agent, was used as $2 \mathrm{mg} / \mathrm{ml}$ into drinking water.

\section{Diabetic Experimental Groups}

5 separate experimental groups were formed, 6 in each group, and the following procedures were applied to the groups.

Hyperglycemic control group: In order to compare the values of the groups formed, only STZ and diabetic control group $(\mathrm{n}=6)$ 


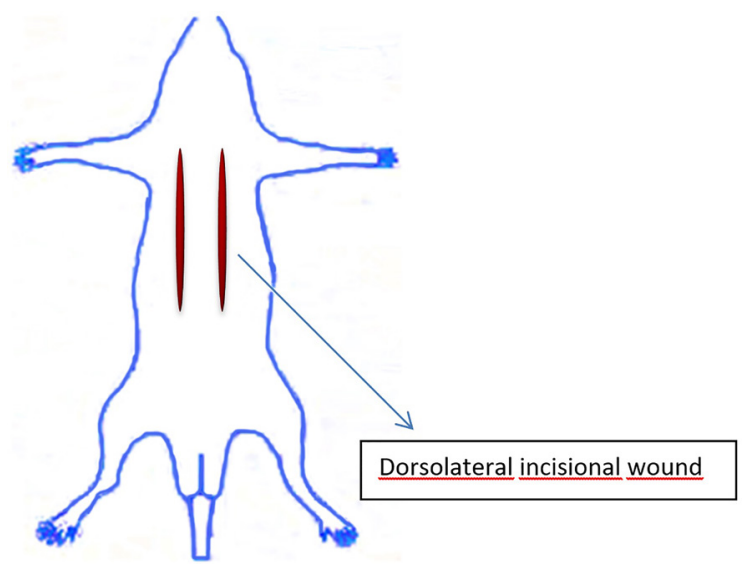

Figure 1. Incisional wound model

Hyperglycemic untreated groups: After being diabetic with STZ, only the wounded group (3rd day of healing was sacrificed) $(n=6)$ After being diabetic with STZ, only the wounded group (7th day of healing was sacrificed) $(n=6)$

Hyperglycemic bFGF treated groups: The group that was wounded after being diabetic with STZ and applied bFGF (3rd day of recovery was sacrificed) $(n=6)$ The group that was wounded after being diabetic with STZ and applied bFGF (7th day of recovery was sacrificed) $(n=6)$

After the applications, the rats were sacrificed by taking blood from their hearts on the 3rd and 7th days in accordance with the chronobiological order. The blood samples taken were centrifuged at $3000 \mathrm{rpm}$ for 15 minutes and the serums were taken into ependof tubes and stored at $-30^{\circ} \mathrm{C}$ until analyzed.

\section{Biochemical Analyses}

\section{Determination of TBARs Levels}

The determination of MDA, which is the indicator of lipid peroxidation, was made by the method of thiobarbituric acid reactive substance (TBARS) formation using Kurtel method [27]. The solutions used are 15\% TCA, 0.02\% BHT (in 95\% ethanol), 0.375\% TBA and $0.25 \mathrm{~N} \mathrm{HCl} .400$ $\mu \mathrm{L}$ of TBA-TCA-HCl mixture (in equal amounts) was added onto $200 \mu \mathrm{L}$ of plasma and vortexed. After being kept at room temperature for 5 minutes, it was centrifuged at $10000 \mathrm{rpm}$ for 5 minutes. The entire supernatant obtained was placed in glass tubes. After adding $4 \mu \mathrm{L}$ of BHT to the supernatants, the tubes were boiled for 15 minutes. After cooling in tap water, it was placed in an ELISA plate and read at a wavelength of $532 \mathrm{~nm}$.

\section{Determination of RSH Levels}

Determination of plasma total sulfhydryl groups (RSH), which is an indicator of antioxidant capacity, was made by spectrophotometric method [27]. The solutions used are the mixture containing $10 \mathrm{~m} \mathrm{M}$ DTNB, $100 \mathrm{mM}$ Tris$\mathrm{HCl}$ (pH 8.2), 1\% SDS-2 mM EDTA in 0.1 M potassium phosphate buffer (pH: 7). $1 \mathrm{~mL}$ of Tris-SDS-EDTA mixture was added to $500 \mu \mathrm{L}$ sample. It was incubated for 5 minutes at room temperature, and then centrifuged at $10000 \mathrm{rpm}$ for 5 minutes. $40 \mu \mathrm{L}$ DTNB was added to the obtained supernatant. After being kept at $37^{\circ} \mathrm{C}$ for 20 minutes, it was read at $412 \mathrm{~nm}$ wavelength on the ELISA reader.

\section{Determination of Total NOx Levels}

The modified Griess method was used for the determination of NOx, which is the sum of plasma nitrite and nitrate[28]. 0-50 $\mu \mathrm{M}$ dilutions of sodium nitrate $\left(\mathrm{NaNO}_{3}\right)$ prepared with deionized water were used as standard. 0.3 $\mathrm{N} \mathrm{NaOH}$ was completed to $100 \mathrm{ml}$ by adding deionized water to $1.2 \mathrm{~g}$ of $\mathrm{NaOH} .10 \% \mathrm{ZnSO}_{4}$ is completed to 100 $\mathrm{ml}$ by adding deionized water on $10 \mathrm{~g}$ of $\mathrm{ZnSO}_{4} . \mathrm{VaCl}_{3} 4.2$ $\mathrm{ml} \mathrm{HCl}$ was added to $0.4 \mathrm{~g} \mathrm{VaCl}_{3}$ and this mixture was completed to $50 \mathrm{ml}$ with deionized water. Sulfanolamide 2 gr sulfanolamide $13.6 \mathrm{ml} \mathrm{HCl}$ was added and this mixture was completed to $100 \mathrm{ml}$ with deionized water. -NEDD (N- (1-naphtyl) ethylenediamide dihyrochloride) was completed to $100 \mathrm{ml}$ by adding deionized water on 0.1 gr NEDD. $100 \mu \mathrm{L} 0.3 \mathrm{M} \mathrm{NaOH}$ was added to $100 \mu \mathrm{L}$ plasma and incubated for 5 minutes at room temperature. $100 \mu \mathrm{L}$ of $10 \% \mathrm{ZnSO}_{4}$ was added to this mixture and vortexed. The resulting mixture was centrifuged at $+4^{\circ} \mathrm{C}$ at $14000 \mathrm{rpm} .100 \mu \mathrm{L}$ of each of the supernatants obtained after centrifugation was placed on a 96-well ELISA plate. The samples were placed on the plate in duplicate with the same volume of standard solutions. $100 \mu \mathrm{L}$ of $\mathrm{VaCl}_{3}$ was added to all samples and standard solutions, followed by $50 \mu \mathrm{L}$ of sulfanolamide and $50 \mu \mathrm{L}$ of NEDD. The plate was incubated at $37^{\circ} \mathrm{C}$ for 30 minutes. At the end of the incubation it was read on an ELISA reader at a wavelength of $540 \mathrm{~nm}$.

\section{Statistical Evaluation}

All values are expressed as arithmetic mean \pm standard error. The values obtained were evaluated using Anova analysis of variance (one-way ANOVA) and Tukey multiple comparison test (SPSS 16.0 for Windows (SPSS, Inc., Chicago, USA). P value of $<0.05$ was considered statistically significant.

\section{RESULTS}

Morphological images of the wounds belonging to the untreated and treated groups of hyperglycemic rats and their changes depending on the days, blood samples ta- 
ken are shown in Figures 2, 3, 4 and 5.

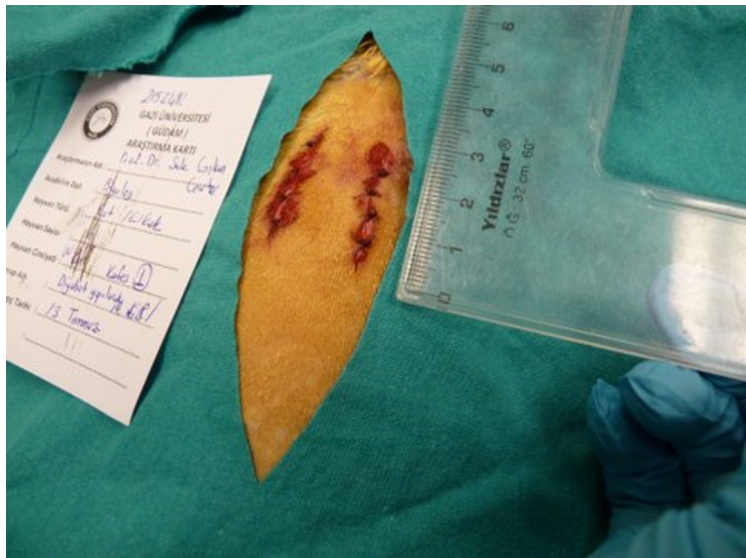

Figure 2. Dorsolateral incisional wound

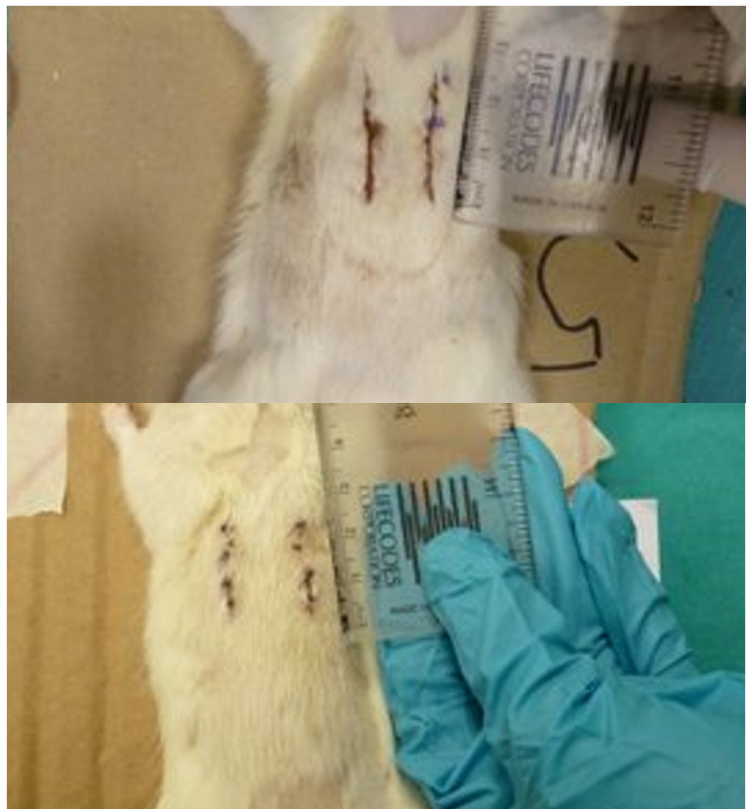

Figure 3. Morphological image of hyperglycemic 3-day untreated and bFGF 3-day treated wounds

Findings of the oxidative parameters of TBARS, RSH and NOx in the control group, treated and untreated groups in hyperglycemic rats are shown in Table 1.

\section{Serum TBARS Levels in Hyperglycemic Rats}

TBARS level is measured to determine malondialdehyde, the final product of lipid peroxidation. When the 7 days untreated and treated groups were compared with the control group, a significant increase was observed ( $\mathrm{p}$ $<0.05$ ) (Table 1 and Figure 6).Serum TBARS levels statistically increased on the 7th day compared to the 3rd day in hyperglycemic rats treated with bFGF ( $<<0.05)$ (Table 1 and Figure 6).

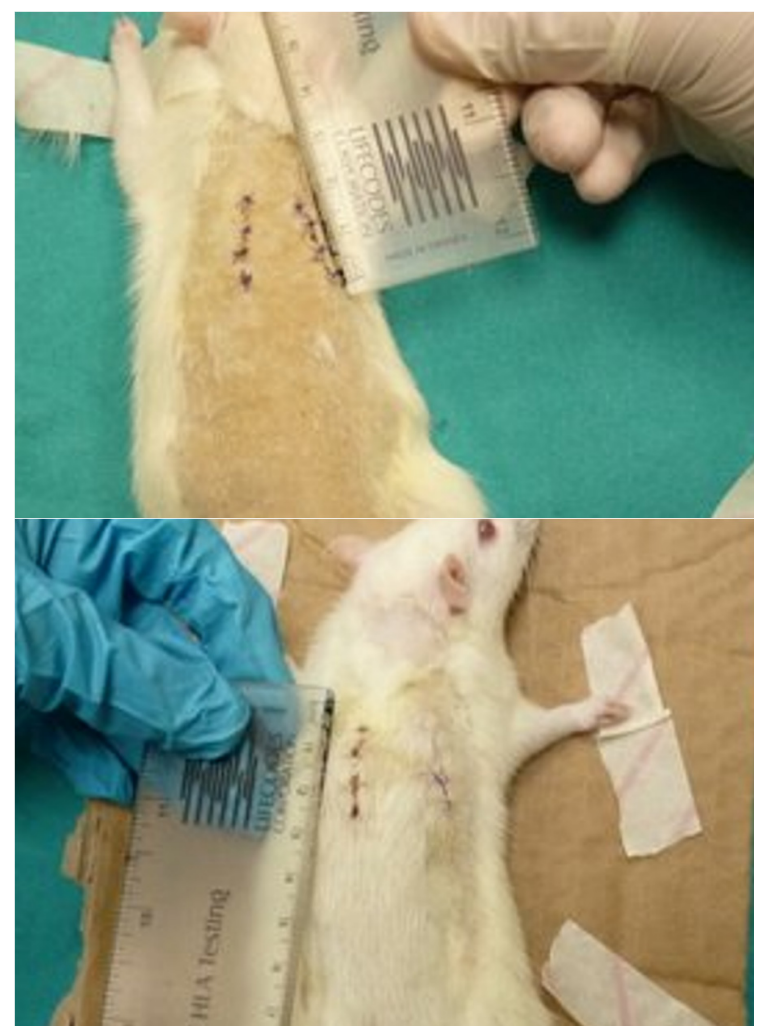

Figure 4. Morphological image of hyperglycemic 7-day untreated and 7-day bFGF-treated wounds

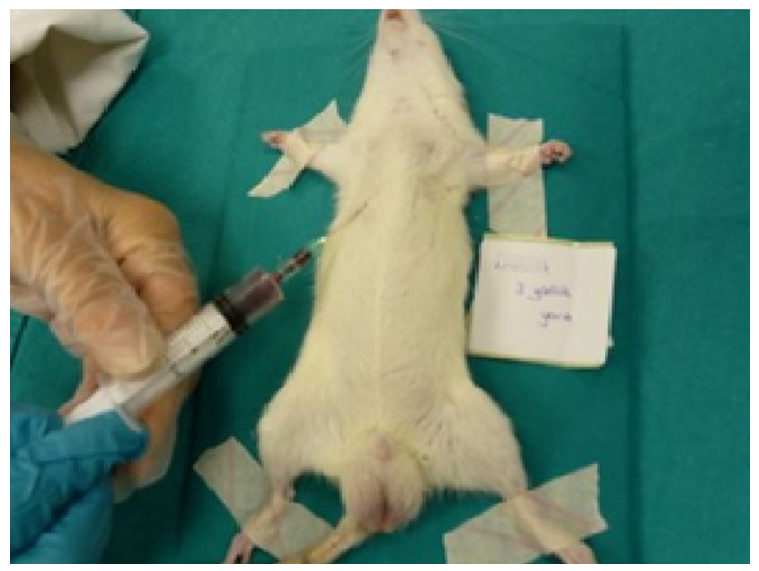

Figure 5. Taking blood samples

\section{Serum RSH Levels in Hyperglycemic Rats}

When the 7th day of the bFGF applied rats and the 7th day of the untreated group were compared, a significant decrease was detected $(\mathrm{p}<0.05)$ (Table 1 and Figure 7)

It was observed that the RSH levels in rats treated with bFGF decreased compared to the 3rd and 7th days. $(\mathrm{p}<0.05)$ (Table 1 and Figure 7). Both in the 3rd day of the untreated 
Table 1. Serum TBARS, RSH and NOx levels in hyperglycemic rats

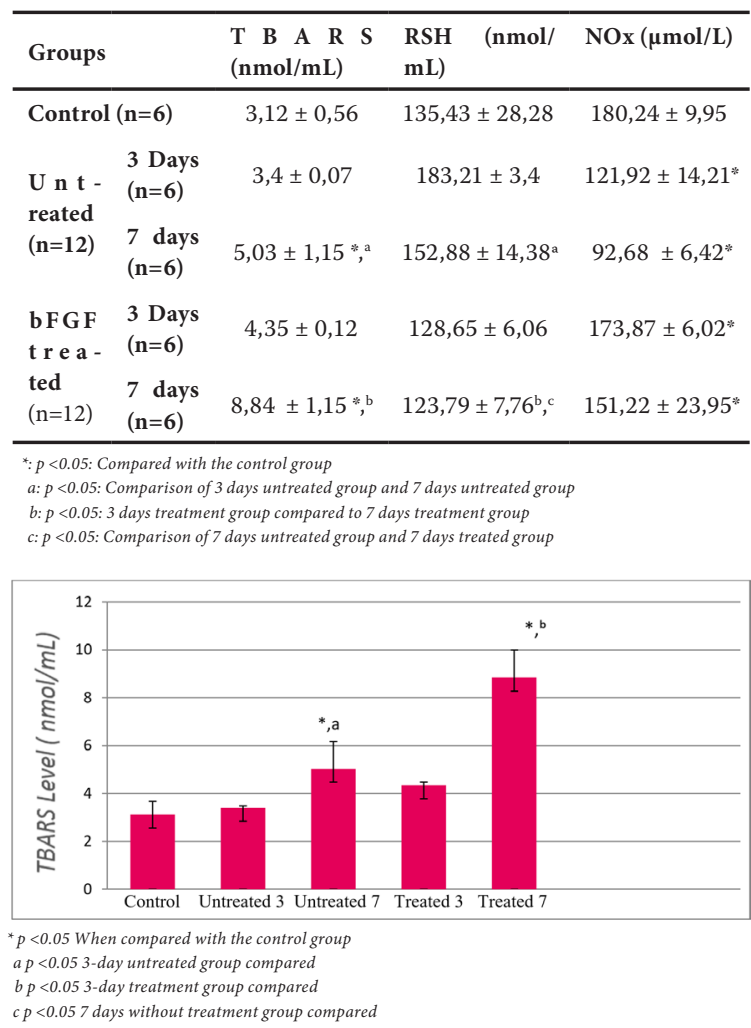

Figure 6. Serum TBARS ( $\mathrm{nmol} / \mathrm{mL}$ ) levels in hyperglycemic rats

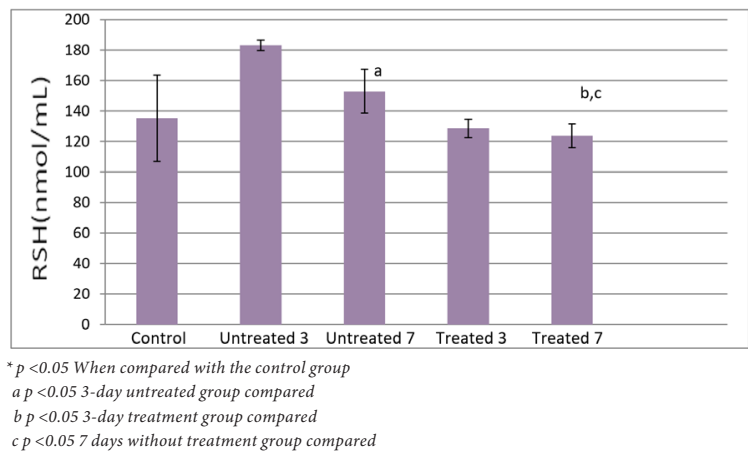

Figure 7. Serum RSH (nmol / mL) levels in hyperglycemic rats

and 3rd day of the rats treated with bFGF may significant decrease in the serum RSH levels.

\section{Serum NOx Levels in Hyperglycemic Rats}

A statistically significant increase was found in rats treated with hyperglycemic bFGF when compared with the NOx levels of the 3rd day of wound healing and the same day of the untreated group $(\mathrm{p}<0.05)$. Nitric oxide levels increased with the bFGF treatment we applied. When all groups were compared with the control, a statistically significant difference was found $(\mathrm{p}<0.05)$ (Table 1 and Figure 8).

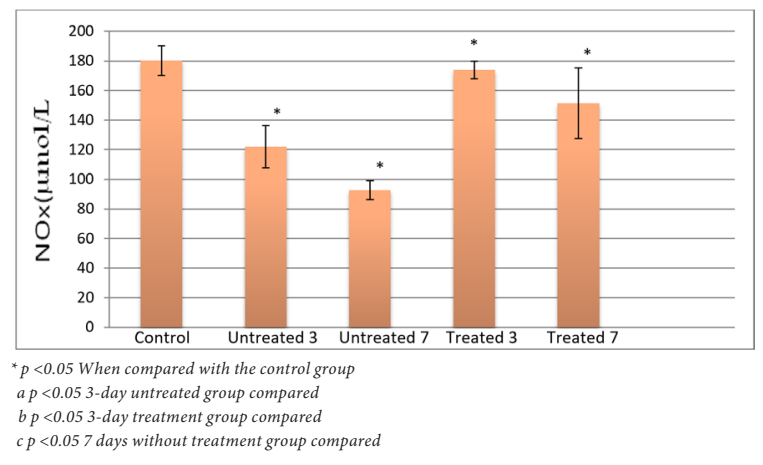

Figure 8. Serum levels of NOx ( $\mu \mathrm{mol} / \mathrm{L})$ Levels in hyperglycemic rats

\section{DISCUSSION}

Free radicals affect organic compounds as a result of oxidative reactions and cause various biological problems [29]. The oxidative balance is disturbed when an increase in the rate of radical formation or a decrease in the rate of their removal is observed. Oxidative stress may reduce the effect of antioxidants and cause tissue damage. With the oxidative stress that occurs, the effect of antioxidants may decrease, resulting in tissue damage [30].

It can be said that bFGF significantly reduces oxidative stress and plays an important role in suppressing this damage.

The research is limited to the bFGF treatment applied to rats by the researchers and the data obtained biochemically. Çetin et al. (2004) pointed out that bFGF has a scavenging effect on free radicals that occur with respiratory burst, which is effective in the inflammatory phase of wound healing [31]. The production of $\mathrm{H}_{2} \mathrm{O}_{2}$ and ROS in the inflammatory process in the wound area causes increases in the TBARS level. Inflammatory responses are required for wound repair following injury [32].In our current findings, the negative effect of diabetes, lipid peroxidation in hyperglycemic rats with bFGF application could not be eliminated. The reason for this can be shown as increased oxidative stress due to diabetes.bFGF has a very short biological half-life (2-3 min). It can be rapidly removed from the blood when injected. For this reason, suitable systems such as controlled release systems should be used to increase the release time and eliminate its undesirable effects[31].Wei et al. (2009) emphasized in their research that the FGF family shows antioxidant properties in conditions related to oxidative stress [33]. In our experiment, the high TBARS levels in the treated 7-day group indicate that bFGF in serum did not have an antioxidant effect. Due to the strong link between diabetes and free radicals in the studies, it can be said that bFGF application against free radicals should be done at a more appropriate dose. In addition, it is necessary to provide long-term release of bFGF to increase the in vivo efficacy. 
There are antioxidant systems that protect the body against free radical damage at many stages. Antioxidants are negatively affected by the oxidative stress caused of free radicals. Antioxidants used to prevent the effect of free radicals, especially thiol groups, can't protect the plasma and tissue levels due to interactions [34]. All plasma-SH groups are associated with proteins. With the increasing oxidative stress, $-\mathrm{SH}$ groups found in plasma and membranes are oxidized by free radical effect and a decrease in their reduced form is detected. GSH is required for the oxidized thiol groups to become reduced again and to be used in oxidative damage. While GSH neutralizes thiol groups affected by oxidative stress, it falls short[34, 35]. Both in the 3rd day of the untreated and 3rd day of the rats treated with bFGF may significant decrease in the serum RSH levels. The decrease in RSH levels of treated diabetes groups compared to untreated diabetes groups is that plasma proteins may be sensitive to bFGF, especially due to free sulfhydryl groups in the serum albumin structure. The molecular structure of bFGF could not positively affect the oxidative stress that increases with diabetes.

Nitric oxide levels increased with the bFGF treatment we applied. Topical application of bFGF decreased NOx levels and nitrite oxide synthase enzyme was suppressed. In the light of this information, bFGF application in diabetic rats contributed to wound healing systemically. NO is an endothelium-derived vasodilator agent and plays an active role in lowering blood pressure. It is one of the important molecules in the wound healing process. While it has a protective effect at physiological doses, it can show a cytotoxic effect at high levels [30]. NO is rapidly metabolized to nitrite and nitrate by interacting with the Hem group of hemoglobin in the blood. NO also reacts with heme and other ironcontaining molecules, and with thiol (- $\mathrm{SH}$ ) groups of proteins [36]. A statistically significant increase was found in rats treated with hyperglycemic bFGF when compared with the NOx levels of the 3rd day of wound healing and the same day of the untreated group ( $\mathrm{p}<0.05)$. In hyperglycemic rats, there was an increase in NO production due to the increased leukocyte activation during the inflammation phase of wound healing and its effect preventing leukocyte outflow. The decrease in nitrite oxide production in the endothelium has been blamed for the disorders of endothelial functions seen in diabetes, although controversial [37]. However, there are also studies showing that NO is increased in diabetes [38].

\section{CONCLUSION}

It can be said that bFGF significantly reduces oxidative stress and plays an important role in suppressing this damage. In this study, information about how bFGF, which is known to have an effect on wound healing, mana- ges oxidative events was tried to be clarified. When all the information is evaluated, our study has shown that bFGF applied to dorsolateral incision wounds created in hyperglycemic rats has a regulatory effect on serum levels of oxidative events. It has been shown that this effect may vary depending on the days, the stages of wound healing and the dose administered. In subsequent studies, the effect of bFGF, which has positive effects on diabetic wound healing, on oxidative events can be investigated in detail by using different doses and different treatment times.

\section{ACKNOWLEDGEMENT}

This study was supported by a research grant from TÜBİTAK (215Z482).

\section{CONFLICT OF INTEREST}

Esra Oguz confirms, on behalf of all authors, that the information provided is accurate.

\section{AUTHOR CONTRIBUTION}

Esra Oğuz and Sule Coskun Cevher designed the study. EO performed all experiments. EO and SCC analysed the data. EO and SCC wrote the paper.

\section{References}

1. Yüceyar, S., Cerrahi Yaraların Takip ve Tedavisi. Yara Bakımı ve Tedavisi., İ.Ü Cerrahpaşa Tip Fakültesi Sürekli Tip Eğitimi Etkinlikleri. (2008) p. 17.

2. Lazarus, G.S., et al., Definitions and guidelines for assessment of wounds and evaluation of healing. Wound repair and regeneration, (1994). 2(3): p. 165-170.

3. Barrientos, S., et al., Growth factors and cytokines in wound healing. Wound Repair and Regeneration, (2008). 16(5): p. 585-601.

4. Karasu, A. and B. Bakır, Yara ve yara iyileşmesi. Veteriner Cerrahi Dergisi. (2008) . 36-43.

5. Taşır, S., Ekzojen epidermal büyüme faktörü’nün tükürük bezi oksidan olaylarına zaman bağımlı etkisi. Fen Bilimleri Enstitüsü. Gazi Üniversitesi. 2007.

6. Takayama, Y. and R. Aoki, Roles of lactoferrin on skin wound healing. Biochemistry and Cell Biology. (2011). 90(3): p. 497-503.

7. Anusaksathien, O. and W.V. Giannobile, Growth factor delivery to re-engineer periodontal tissues. Current Pharmaceutical Biotechnology. (2002). 3(2): p. 129-139.

8. Lee, S.J., Cytokine delivery and tissue engineering. Yonsei Medical Journal. (2000). 41(6): p. 704-719.

9. Ornitz, D.M. and N. Itoh, Fibroblast growth factors. Genome Biology. (2001). 2(3): p. 1-12.

10. Casey-Sawicki, K., et al., A basic fibroblast growth factor analog for protection and mitigation against acute radiation syndromes. Health Physics. (2014). 106(6): p. 704- 712.

11. Teven, C.M., et al., Fibroblast growth factor (FGF) signaling in development and skeletal diseases. Genes \& Diseases. (2014). 1(2): 
p. 199-213.

12. Özbek, Z. and Vural M., Kranial Sütürlerin Biyolojisi, Sütür Büyüme, Gelişme ve Kapanmasının Regülasyonu. Türk Nöroşirürji Dergisi. (2017). 27(3): p. 245-250.

13. Kobayashi, F., K. Matsuzaka, and T. Inoue. The effect of basic fibroblast growth factor on regeneration in a surgical wound model of rat submandibular glands. International Journal of Oral Science. (2016). 8(1): p. 16-23.

14. Özler, M., et al., Pinealektomili ratlarda yara iyileşmesi. Gulhane Medical Journal. (2010). 52: p. 181-184.

15. Brogard, J., T. Vetter, and J. Blickle, Discovery of pancreatic diabetes in Strasbourg. Diabete \& Metabolisme, (1992). 18(2): p. 104-114.

16. Baynes, J.W. and S.R. Thorpe, Role of oxidative stress in diabetic complications: a new perspective on an old paradigm. Diabetes. (1999). 48(1): p. 1-9.

17. Dandona, P., et al., Oxidative damage to DNA in diabetes mellitus. The Lancet. (1996). 347(8999): p. 444-445.

18. Aslan, D., Onat, T., Emerk, K. And Sözmen, E. Y, İnsan Biyokimyası, second edition, Ankara: Palme Publishing. 2006.

19. Pitocco, D., et al., Oxidative stress, nitric oxide, and diabetes. The Review of Diabetic Studies: RDS. (2010). 7(1): p. 15.

20. Hu, C., et al., Basic fibroblast growth factor stimulates epithelial cell growth and epithelial wound healing in canine corneas. Veterinary Ophthalmology. (2009). 12(3): p. 170-175.

21. Xie, J., et al., Effects of basic fibroblast growth factor on the expression of extracellular matrix and matrix metalloproteinase-1 in wound healing. Clinical and Experimental Dermatology: Continuing professional development (CPD), (2008). 33(2): p. $176-$ 182

22. Erarslan, S., Bazik fibroblast büyüme faktörü uygulamasının yara dokusu oksidan olaylarına etkisi, Biyoloji Anabilim Dalı. Gazi Üniversitesi. (2019).

23. Alimohammadi S, Hobbenaghi R, Javanbakht J, Kheradmand D, Mortezaee R, Tavakoli M, Khadivar F, Akbari H. Protective and antidiabetic effects of extract from Nigella sativa on blood glucose concentrations against streptozotocin (STZ)-induced diabetic in rats: an experimental study with histopathological evaluation. Diagn Pathol. (2013) Aug 15;8:137.

24. Masson-Meyers, D.S., et al., Experimental models and methods for cutaneous wound healing assessment. Int J Exp Pathol, (2020). 101(1-2): p. 21-37.
25. Laila, L., et al., Wound healing effect of Haruan (Channa striatus) spray. International Wound Journal, (2011). 8(5): p. 484-491.

26. Gökşen, S., Diyabetik ratlarda topikal trombosit kökenli büyüme faktörü'nün yara dokusu oksidatif olayları üzerine etkisinin incelenmesi, Fen Bilimleri Enstitüsü. Gazi Üniversitesi. (2014).

27. Kurtel, H., et al., Vulnerability of intestinal interstitial fluid to oxidant stress. American Journal of Physiology-Gastrointestinal and Liver Physiology. (1992). 263(4): p. G573-G578.

28. Miranda, K.M., M.G. Espey, and D.A. Wink, A rapid, simple spectrophotometric method for simultaneous detection of nitrate and nitrite. Nitric Oxide. (2001). 5(1): p. 62-71.

29. Aydemir, B. and E.K. SARI, Antioksidanlar ve büyüme faktörleri ile ilişkisi. Kocatepe Veterinary Journal, (2009). 2(2): p. 56-60.

30. Altan, N., Dinçel, A. S., and Koca, C., Diabetes Mellitus ve Oksidatif Stres. Türkiye Biyokimya Dergisi, (2006). 31 (2); 51-56.

31. Çetin, M. and Y. Çapan, bFGF Bazik Fibroblast Büyüme Faktörü ve Formülasyonlarında Yeni Yaklaşımlar. Hacettepe University Journal of the Faculty of Pharmacy, (2004). (2): p. 107-124.

32. Rajasekaran, N., et al., The effect of finger millet feeding on the early responses during the process of wound healing in diabetic rats. Biochimica et Biophysica Acta (BBA)- Molecular Basis of Disease, (2004). 1689(3): p. 190-201.

33. Wei, W., et al., Oxidative stress, diabetes, and diabetic complications. Hemoglobin. (2009). 33(5): p. 370-377.

34. Yazıc1, A.E et al., Tip II Diabetes Mellituslu Hastalarda Plazma Total Tiyol ve Eritrosit Redükte Glutatyon Düzeyleri. T Klin J Med Sci (2002). 487-492.

35. Hu, M. L. [41] Measurement of protein thiol groups and glutathione in plasma. Methods in enzymology, (1994). 233, 380-385.

36. Karabağ, F., Deneysel Olarak Hipertiroidizm Olusturulan Ratlarda Kafeik Asit Fenetil Ester'in Plazma Homosistein, Asimetrik Dimetil Arjinin, Nitrik Oksit ve Lipid Profili Üzerine Etkilerinin Araştırılması. Sağlık Bilimleri Enstitüsü. Afyon Kocatepe Üniversitesi. (2010).

37. Chin, Gloria A., Robert F. Diegelmann, and Gregory S. Schultz. Cellular and molecular regulation of wound healing. Basic and Clinical Dermatology. 33 (2005): 17.

38. Memişoğulları, R., Diyabette serbest radikallerin rolü ve antioksidanların etkisi. Duzce Medical Journal, 2005. 7(3): p. 30-39. 